\title{
Europe as spatial imaginary? Narratives from higher education 'policy influencers' across the continent
}

\section{Rachel Brooks, University College London}

\begin{abstract}
Europe is, in many ways, of central importance to discussions about higher education. Various European initiatives, such as the Bologna Process and the Erasmus mobility programme, have had a direct and material impact on the shape and nature of higher education across the continent. They have also been linked to wider political objectives, such as the inculcation of a European political identity, and the strengthening of the European political and economic space relative to other parts of the world. Nevertheless, the relationship between Europe and education has tended to remain rather marginalised within research. We know relatively little, for example, about how policymakers think about Europe and the extent to which it constitutes an important frame of reference for them. To start to redress this gap, we draw on an analysis of policy documents and interviews with key policy stakeholders to argue that the idea of Europe constitutes an important 'spatial imaginary' for higher education within the continent, and helps to frame the ways in which students are conceptualised. However, we also suggest that this is not played out in uniform ways; there are significant differences between both countries and different groups of policy actors within them.
\end{abstract}




\section{Europe as spatial imaginary? Narratives from higher education 'policy influencers' across the continent}

\section{Introduction}

Europe is, in many ways, of central importance to discussions about higher education (Gornitzka, 2007; Robertson, 2009). Various European initiatives, such as the Bologna Process and the Erasmus mobility programme, have had a direct and material impact on the shape and nature of higher education across the continent (Cairns et al., 2018; Keeling, 2006). They have also been linked to wider political objectives, such as the inculcation of a European political identity, and the strengthening of the European political and economic space relative to other parts of the world. Nevertheless, the relationship between Europe and education has tended to remain rather marginalised within research, particularly that conducted within Anglophone countries. We know relatively little, for example, about how policymakers think about Europe and the extent to which it constitutes an important frame of reference for them. To start to redress this gap, in this article, we draw on an analysis of policy documents and interviews with key policy stakeholders to argue that the idea of Europe constitutes an important 'spatial imaginary' for higher education within the continent, and helps to frame the ways in which students are conceptualised. However, we also suggest that this is not played out in identical ways across and within nations; there are significant differences between both countries and different groups of policy actors within them. In this way, we extend the established literature on the Europeanisation of higher education (see for example, seminal work by scholars such as Amaral et al. (2009), Corbett (2005), Maassen and Musselin (2009) and Robertson (2009)). The first part of the article provides a background to the analysis that follows. Here, we explore some of extant literature on the 
relationship between Europe and higher education, before going on to discuss the concept of a 'spatial imaginary', which provides the theoretical framework for the subsequent analysis. We then outline the research methods that underpinned the study, before developing our key arguments.

\section{Background}

\section{Higher education and Europe}

As noted above, the influence of Europe on education has, historically, received relatively little attention from researchers, particularly those located within English-speaking nations. This has been explained in terms of scholars' interest in understanding processes of Europeanisation through analysis of the role of institutions and structures in promoting topdown change, rather than the impact of other fields of activity, such as education, and also as a result of the 'methodological nationalism' of many researchers, in which education is conceived as a discrete national policy field, with few influences from abroad (Grek, 2015). Grek (2015) argues that, as a result, 'education research (at least in the Anglophone tradition) has lost much of its creative, inquisitive potential to locate and sociologically analyse a number of its actors who acts as brokers between their national loci and "Europe"'. Nevertheless, studies that have focussed on the influence of European initiatives on education have indicated that it is significant. Indeed, various scholars have argued that a distinct European education space has been formed through, for example, the operation of various 'soft governance' devices (Lawn, 2009), and the use of comparative data (Grek et al., 2009). Lawn (2009) has thus argued: 'The European Space is more than an ill-defined space of regulation or flows; it is a space of attraction and meaning, in which soft power is at work, 
creating a space in which actors are drawn to work within it and to produce it' (p.272). More specifically, Corbett's (2005) detailed analysis of the relationship between universities and the idea of a 'Europe of knowledge' shows how serious attention was given to higher education by a variety of European policymakers from the late 1950s onwards, and how 'policy entrepreneurship' by well-placed individuals was key to advancing the idea of the European Community playing a role within higher education. Adopting a rather different perspective, Carlson et al. (2018) have contended that while attempts at top-down Europeanisation have been subject to intense conflict and are deemed highly political, initiatives in the area of culture and education have been conceived differently and much less contentiously - typically as bringing people together in a European spirit and thus contributing to social integration. Moreover, learning itself has come to occupy a central role in the way in which Europe is governed, through the emphasis on 'policy learning' encouraging national policy actors to learn with and from their counterparts across Europe, and comparing data from across the continent to inform local practice (Grek, 2015; Kerber and Eckardt, 2007).

The relative lack of scholarly attention to Europe is also related to the fact that the European Commission's competence in the area of education was widely opposed up until the late 1980s; policy in this area was generally conceived as a distinctly national affair (Berndtson, 2013). This changed, however, with the introduction of the Erasmus student mobility programme in 1987, and the emergence of the European Credit Transfer System two years later to help facilitate movement between European universities and degree programmes (ibid.). Since then, education has gained an increasingly high priority within European initiatives. The Maastricht Treaty of 1992, for example, formally recognised higher education as an area of European Union competence, and gave the European Commission the right to 
encourage co-operation in education. However, the treaty also specified the limits to the Commission's influence, by noting that member states retained full responsibility for the content of teaching, the organisation of their education systems and cultural and linguistic diversity. Thus, the Commission's attempts to shape higher education in this period were confined largely to publishing reports and funding specific projects.

The Lisbon Strategy, published in 2000 and reformulated in 2005, positioned higher education as a key means of making Europe 'the most competitive and dynamic knowledgebased economy in the world' and, as a result, strengthened demands on the part of the European Commission for governance and funding reforms within the European Union's (EU) universities. Indeed, Gornitzka (2007) has argued strongly that it was the Lisbon Strategy (rather than subsequent initiatives, such as the Bologna Process, discussed below), that was fundamentally responsible for the increasing prioritisation given to higher education by the European Commission. She contends:

In the Lisbon Strategy, the University, as part of education and research systems in Europe, was envisioned as a core institution of the 'Europe of knowledge' ... the Lisbon process directed the attention of education and research much more broadly in making them the means to reach the ambition of socially and environmentally sustainable economic growth. (p.155)

Around the same time, higher education was also foregrounded within Europe through the Bologna Process, which began with the signing of the Paris Declaration in 1999. Signatories agreed to: adopt a system of easily readable and comparable degrees (based on two main degree cycles); implement a system of European learning credits; support the mobility of students and staff; promote European co-operation in quality assurance; and encourage a 
European dimension in higher education (through curriculum development and interinstitutional co-operation) (Soltys, 2015; Szolar, 2011). The Bologna Declaration was an inter-governmental initiative, not one driven by the European Union. Indeed, the European Commission's role in the Bologna Process was not made official until 2001. However, many scholars argue that, since then, the Commission's influence has been significant. Berndtson (2013) maintains that it has a led to a convergence of the Bologna Process with the Lisbon agenda, and a consequent shift of emphasis away from issues of curriculum reform to a more direct focus on employability and the labour market. Various scholars have argued that the Bologna reforms, and those associated with the European Higher Education Area (EHEA) (announced in 2010 by those involved in the Bologna Process), have led to a significant degree of homogenisation - of structures, principles and broader understandings of the purpose of higher education - across the continent, through the substantive reforms themselves, and also the values that underpin them (Voegtle et al., 2011). In seeking to explain why a system initially predicated on voluntary participation was so widely implemented across Europe, and at such speed, Ravinet (2008) contends that three factors were significant: the Bologna reforms were embraced because they were typically understood as part of the paradigm of the knowledge-based economy; they were often used to justify national reforms that governments wanted to pursue anyway; and the initial emphasis on voluntary participation evolved into a system of monitored co-ordination. Writing with respect to Germany, in particular, Münch (2013) has maintained that the Bologna reforms have fundamentally altered the orientation of the higher education system - away from its traditional role of enabling research and the education of public servants, and towards a much closer relationship with the market. Discussing the impact on Europe more broadly, Moutsios (2013) has argued that Bologna's influence has been significant: 
Politics about the university is displaced by transnational policymaking networks dominated by business interest groups and mechanisms of objective-based steering and performance monitoring; corporate management is disintegrating the academic community, subduing the staff as a workforce under surveillance and positioning students as consumers; universities are being regarded as part of the EU's 'knowledge industry'; and academics not as independent scholars but as 'brainpower' subject to the competition strategies of the business world ....in addition, scholars are being required to teach knowledge demanded by the labour markets and standardize the language and organisation of their teaching. (p.40-41)

While other scholars have disputed the extent to which business interests have infused university politics and practices, most have acknowledged that neo-liberalism more generally has underpinned the Bologna reforms and has had a profound impact on universities across Europe. Amaral (2008), for example, has argued that, since the turn of the $20^{\text {th }}$ century, governance models of higher education and the relationship between higher education institutions and governments have both undergone significant change - with the emergence of a new rhetoric based on management and efficiency, the adoption of market-based mechanisms, and the replacement of values associated with autonomy and academic freedom with the criteria of economic rationality. Moreover, while noting some important differences between countries (see discussion below), Dobbins' (2011) Europe-wide analysis identified what he described as a 'sluggish convergence' (p.181) towards market-oriented models of higher education.

There is also however a sizable body of literature that has raised important questions about the extent to which higher education across Europe has homogenised as a result of these various initiatives (as well as neo-liberal pressures more generally). First, scholars have pointed out significant differences by nation-state in the ways in which European reforms, 
such as those associated with the Bologna Process and the European Higher Education Area, have been implemented - and also in the meanings attached to the reforms. Dobbins and Knill (2017) have contended that individual, national higher education systems 'are still anchored in country-specific regulatory regimes, which reflect national-historical, institutional and cultural developments' (p. 67), while Dakowska and Harmsen (2015) have shown how - in central and Eastern Europe at least - processes of Europeanisation and internationalisation have been mediated domestically. They argue that structures (i.e. national policy-making processes), norms (such as the particular university model that has been dominant, historically, within nation-states) and actors (including both individual policy entrepreneurs and international organisations) all play a significant role in such mediation. Writing with reference to the Bologna reforms more specifically, Soltys (2015) has argued that they have been implemented less fully in post-socialist countries than in their western European counterparts, largely because of their statist legacy and the relatively weak power of civic actors. He writes:

The over-emphasis [in post-socialist countries] on bureaucratic checks and controls negates two important aspirations of Bologna: on the one side, university autonomy, empowerment of faculty, and development of local communities; and on the other side, the free flow of international knowledge. (p.192)

In Poland, implementation of Bologna reforms has been entangled with wider political priorities and, in particular, negotiations about accession to the European Union. Indeed, Dakowska (2015) maintains that European Higher Education Area measures have been seen by politicians largely as part of a non-negotiable 'European package', to be implemented as soon as possible, and which has been communicated to the Polish people as a means of 'catching up with the West' (see also Szolár, 2011). She also notes, however, that European 
higher education reforms have been used strategically by policymakers, to push through reforms that they were keen to champion anyway, related to increasing both competition within public services, and the flexibility of the workforce. Some similarities have also been noted with respect to Ukraine - with the adoption of Bologna reforms bringing about symbolic benefit, in terms of alignment with western Europe, rather than substantive change within the higher education system (Shaw et al., 2013) - and in France, with government officials using the Bologna Process primarily to serve national ends (Musselin, 2009). In many ways, these examples illustrate well Capano and Piattoni’s (2011) more general argument about how European education policy often acts as a 'cultural script' from which national actors pick and choose according to their own local priorities. Various scholars have suggested that Bologna measures have been successfully implemented only when particular reforms have aligned well with existing beliefs and values held by higher education actors (Shaw et al., 2013).

Differences have also been highlighted within individual nation-states. Lueg (2018) notes the various frictions between university leaders and academic staff that emerged within Germany because of their different understandings of what Europeanisation meant with respect to academic standards and power relationships within their organisation. Indeed, Lueg goes as far as to argue that, amongst her respondents, the term Europeanisation was so contested that it had no fixed meaning but allowed for significantly different interpretations and courses of action. Similarly, research in higher education institutions in Norway, Portugal, Germany and Italy conducted by Neave and Veiga (2013) indicated that understandings of the Bologna Process were highly fragmented, with each institution having its own perspective defined largely by the priorities it thought it should be addressing locally. They conclude by 
speculating that institutional compliance 'may not necessarily mature into the EHEA, which is seen with a marked lack of interest' (p.67).

Finally, homogenisation has been impeded by the differences in understanding of reform held even by key European actors. For example, Corbett and Henkel (2013) have argued that while the European Commission has tended to view the Bologna process as a key means of delivering the Lisbon agenda - i.e. through underpinning the EU's economic growth and innovation strategy - the European Students' Union and the Council of Europe have focussed instead on the importance of including a social dimension to the Bologna reforms and retaining public responsibility for higher education. The European University Association, in contrast, has prioritised the quality assurance reforms included in the Bologna Process, seeing these not merely as a means of accrediting qualifications and thus enabling student mobility, but a key instrument of improving the quality of educational provision within individual institutions (ibid.). These debates provide an important frame of reference for the analysis of policy documents and policy influencers' narratives that follows below.

\section{Spatial imaginaries}

To theorise the ways in which Europe is discussed within the data, we draw on the concept of 'spatial imaginaries'. Watkins (2015) defines these as socially held stories that constitute particular ways of talking about places and spaces. These stories are usually based on what the tellers hold to be 'facts' about the specific space or place, even if the veracity of such claims may be in doubt (Said, 2003; Watkins, 2015). They can operate at a variety of scales, from the very local (relating to, for example, a town or indeed an individual home) to the national, supranational or even the global (for example, with respect to stories about 
globalisation) (Watkins, 2015). Irrespective of scale, spatial imaginaries are also collective in nature, and typically shared among groups rather than merely held individually. They are also often considered to have agency of their own, helping to shape material practices through producing, reproducing and changing social perceptions of places even among those who have never been to those specific locations themselves. The stories that are told about places cause people to act in particular ways to and through this spatial imaginary; they are thus frequently held to be performative in nature, not merely representational (Gregory, 2004; Watkins, 2015).

Spatial imaginaries can also have a direct impact on beliefs and feelings about belonging and relations to others. Indeed, various scholars have argued that they can play an important role in establishing both bonds within groups and boundaries between groups. Because they often position places hierarchically - categorising some places as better than others - they are commonly implicated in processes of othering (e.g. Bürkner and Scott, 2019; Sykes, 2018). They are also effective vehicles for the transmission of social anxieties and/or hopes about the future (Itaoui, 2016; Wetzstein, 2013).

In his analysis of the way in which the concept of the spatial imaginary has been used within the social sciences, Watkins (2015) usefully distinguishes between three analytical categories. First, he notes that the concept has been used with reference to distinct places ("place imaginaries'), emphasising the uniqueness of the particular location and establishing boundaries between it and other places. In this way, it can contribute to processes of othering alluded to above. However, place imaginaries are not always uncontested; different groups can propagate competing spatial imaginaries of the same location (ibid.). Second, Watkins delineates 'idealised space imaginaries'. These are descriptions of kinds of places, which 
emphasise general stories about their universal characteristics, and can have either a positive or negative orientation:

Positive orientations often argue how specific places should remain an idealized kind of space (like a developed country), 'othering' different places in the process. Negative associations are often used to argue specific places should change from a certain idealized space (like the ghetto) into something else (like the gentrified neighbourhood). (Watkins, 2015, p.513)

Third are what Watkins calls 'spatial transformational imaginaries'. These link specific places to broader fields of social relations through articulating narratives of how places 'have, should, or deterministically will evolve' (ibid., p.513) through generalised spatial processes. Examples might include globalisation, gentrification and deindustrialisation. These stories are often bound up with ideas about inevitability, and frequently naturalised as incontrovertible 'truths'. Writing with respect to education policy specifically, Rizvi and Lingard (2010) have argued that neo-liberal globalisation has acted as a significant 'social imaginary' (similar in its definition to the spatial imaginaries discussed above), and has gained ascendancy over other possible understandings of globalisation. They contend that this has come about, not through a single process, but as a consequence of 'a range of historically specific and interrelated processes which include: the global circulation of ideas and ideologies; international conventions and consensus that steer education policies in a particular direction; cooperation and competition inherent, for example, in the practices of international trade in education; [and] formal bilateral and multilateral contracts between system which offer a high degree of coercion' (p.42).

Watkins' (2015) three-fold categorisation of spatial imaginaries provides an original and useful framework for the discussion that follows in this article, elucidating some of the 
conceptual work being done by the various references to Europe within the policy documents and interviews. In contrast to the methods employed by much of the political science literature in this area (some of which has been cited above), we proceed in an inductive manner, inferring the type of spatial imaginaries deployed from our reading of the data. However, as the subsequent discussion will show, we develop Watkins' theory by arguing that the relationship between 'places' and 'idealised spaces' is complex, with the two concepts often seemingly mutually reinforcing rather than analytically distinct.

\section{Methods}

The article draws upon two main sources of data, collected as part of a larger European Research Council-funded project: a corpus of 92 policy documents, and 26 in-depth individual interviews conducted with a range of 'policy influencers'. Data were collected from six European countries - Denmark, England, Germany, Ireland, Poland and Spain chosen to provide variety in terms of: relationship to the European Union; welfare regime; level of higher education tuition fee; and provision of student support (such as maintenance grants and loans). These characteristics are summarised in Table 1. In each country, between 12 and 16 policy documents were selected, produced by the following groups: government (including key strategy documents and speeches given by higher education ministers); national unions representing higher education staff and students; and bodies representing graduate employers. Documents were chosen based on: the extent to which they focussed on students, specifically; their national significance; and their date of publication (the most recent documents that met the first two criteria were chosen). Where they were not available in English, they were translated prior to analysis. Analysis was conducted using NVivo and 
deployed both deductive and inductive approaches. Some codes were derived from the extant literature (see Brooks, 2018a for details), while others emerged from our analysis.

Interviews were conducted in each of the countries with a similar range of stakeholders, representing: government (a civil servant working on higher education policy and/or a government minister); unions (in most countries a leader of the national students' union, although in Spain we interviewed a leader of a union representing staff); and graduate employers/business organisations. In addition, we interviewed a member of staff from the national body representing universities (often called 'rectors' conferences' in mainland Europe). All interviewees were asked a similar range of questions about how they understood students in their own country and the extent to which their understandings had changed over time. They were also asked about specific ways in which students have been understood by others (for example, as consumers, political actors, future workers) and the degree to which they shared such views. Additionally, they were asked to respond to an extract from a key policy document from their own country. All interviews were conducted in English, audiorecorded and transcribed in full. As with the documents, the interview data were analysed using both deductive and inductive approaches. This dataset was first analysed discretely, and then integrated - during a second stage of analysis - with the policy document analysis. As Table 2 demonstrates, we also produced some basic frequencies, showing the extent to which some key terms, relevant to our analysis, were mentioned in the documents and interviews.

In the discussion below, policy documents are referred to in terms of their country of origin and type (e.g. German government document, Polish union document). The full reference can be found in the Supplementary Material, along with a list of all 92 documents analysed. The 
interviews are referred to by giving the country and organisation in which the interviewee worked.

[Insert Table 1 here]

\section{European spatial imaginaries}

\section{Distinct place - or idealised space?}

The data indicate that Europe acts as a spatial imaginary for some of the policy actors with respect to their conceptualisation of the continent as a distinct place in itself. In such cases, this is often allied to the 'European project' - the idea of building a region in which values and beliefs are shared, and mobility between nation-states is both common and straightforward. Interestingly, although reference to competition and other market mechanisms were alluded to at various points throughout the policy documents, they were typically not positioned as intrinsic parts of the European project (cf. Sin and Tavares, 2018), and notable by their absence in the interviews. Here, there are significant contrasts with some of the academic literature that has discussed the ambiguity that often surrounds conceptualisation of the 'European' model of higher education. Ravinet (2018), for example, has argued that in some contexts it is seen as synonymous with the Lisbon objectives $-\mathrm{a}$ competitive knowledge economy - while in others, the traditional values of European universities are foregrounded, and in others European higher education is understood instead as defined by the Bologna principles of mobility, employment and attractiveness. Indeed, she contends that while the idea of a European model of higher education is often used in opposition to an imaginary American model, it is almost never defined in its own right. 
This particular conceptualisation of Europe, which foregrounded mobility and shared values, was evident in the policy documents from Germany and, in particular, the speeches given by the German minister for higher education. In his speeches we can discern several themes relating to the relationship between Europe and education. First, in the extract below, students are understood as first and foremost European citizens, rather than citizens of their nationstate, and the claim is made, albeit implicitly, that this has been brought about largely because of the Erasmus mobility scheme:

For the 'generation ERASMUS', a Europe with national borders is unthinkable. You feel and understand yourself as a European citizen! (German speech 1)

In a second group of extracts, a claim is made that the appropriate level of response to social challenges is that of the European Union, rather than the nation, and that education and educational mobility play a key role in such responses:

In the face of nationalism and foreclosure, we are focusing on more mobility of young people, trainees and students in Europe. (German speech 1)

We are facing a great humanitarian challenge: Hundreds of thousands of people - mainly young people - are coming to Europe, fleeing from war and repression. First of all, these refugees need food, shelter and medical care. But beside providing these basic necessities, we must also consider another problem: How can we integrate these large numbers of people seeking refuge in Europe? In my view, the answer should be 'Education'. Education is the key to integration. (German speech 3) 
Addressing global challenges in a joint effort will become an increasingly important mission for Europe which will strengthen the community of Member States. (German speech 3)

A third theme, pursued in one of the German speeches, also focuses on the future of Europe. In these extracts, further strengthening Europe is seen as an important aim, and education is again deemed to be central to achieving this.

More education means more curiosity, more willingness to cooperate, more openness. If we want to strengthen Europe, we need to strengthen education. By striving to give all our educational opportunities, we ensure an active society of the future. (German speech 4)

... education and culture are the pillars of a European identity and the precondition for the further development of Europe. (German speech 4)

The Bologna process offers us a unique forum to build bridges between our states and people of different minds. Together with the concrete results, this is a good signal for Europe. (German speech 4)

In these various speeches, Europe is invoked as a distinct place, with an important role to play in the world, and a clear future trajectory. Its uniqueness is alluded to through reference to its specific educational initiatives (the Erasmus scheme and the Bologna process) and its capacity to help resolve seemingly intractable global issues.

Interestingly, however, this clear conceptualisation of Europe as a distinct place is evident only in the German data. This can perhaps be explained with reference to Germany's particular position within the European Union - and also in relation to the cross-European 
debates about migration in 2015 and the years that followed. Germany clearly has a long history as a founder member of key European associations (West Germany was one of the first members of the European Coal and Steel Community, from which the European Economic Community and later the EU evolved) and currently occupies a central position in the 'European project' (Kundnani, 2014). It has thus been heavily invested in the production of a distinct European spatial imaginary. Germany also chose to take on a leadership role within Europe during the so-called 'migration crisis' of 2015. Along with her Austrian counterpart, the German Chancellor, Angela Merkel, decided to by-pass the usual rules of the EU's shared asylum system, in which migrants are meant to apply for asylum in the first EU country they reach, and allow them entry to their countries (Bock and Macdonald, 2019). It has been argued that this form of leadership, and Germany's calls for other European countries to adopt similarly welcoming policies, played a major role in 'exemplifying and setting the agenda for what counts as morally worthy Europeanness' (Macdonald, 2019, p.328). The quotations above illustrate how ideas about this distinctive Europeanness - and the associated spatial imaginary - were also articulated with respect to higher education. (It could be argued that this particular invocation of Europe says as much about Germany as a distinct place as about Europe. Nevertheless, the focus in the speeches quoted above is clearly on understandings of Europe, even if these differ considerably from nation to nation, and it is this which is of interest to us here.)

As noted above, this particular manner of invoking Europe is not evident in any of the other countries in the sample. Indeed, a more common theme in many of the other nation-states is the differences between local higher education students and their counterparts in other European nations. Thus, in these narratives, the distinctiveness of the national context is often 
foregrounded. This is apparent in the examples below from some of the policy influencer interviews.

[German students] are so self-sufficient [from] since they are very young. Basically, these people ... pay for their own studies and work at the same time, with mini-jobs or whatever. And I think the perception of society is maybe more positive because of that [i.e. because they seem less dependent on the state] (Spanish, HEI representatives interviewee)

Irish students are generally eight to twelve months younger than new under graduate entrants in many other European countries. They are more homogeneous and I think there's, they are ... And because they've taken a very broad post-sec ... upper secondary education, of quite a traditional nature, they're in many cases less ... their choices are less well thought through and they're less well prepared for their particular higher education programme. (Irish HEI representatives interviewee)

in Germany, in Switzerland and all sorts of places, they're just, they're just young adults and they get on with it. And society helps them to do that, possibly in more structured ways, financially, because they don't have any fees to worry about and ... grants and in some cases loan systems that are ... maybe more generous and more accommodating. (Irish HEI representatives interviewee)

You know given our new-found enthusiasm for markets and the labour market and everything that's related to it ...I think that the Polish student population, perhaps long with the student populations of other post-communist countries are markedly different than their counterparts in, in Western Europe. (Polish government interviewee 1) 
Although these extracts could be seen to constitute an important assertion of distinct national spatial imaginaries, and an implicit rejection of the European framing evident in the German documents quoted above, an alternative perspective is possible. Indeed, the way in which some interviewees made spontaneous comparisons across Europe suggests that the continent operates as an important frame of reference and is evidence of what can be considered an emerging idealised spatial imaginary. Scholars have suggested that the geographical areas across which educational comparisons are made can help to constitute specific educational spaces (e.g. Desrosieres, 1998). Although such arguments have typically been made with respect to cross-national assessments such as PISA (Programme for International Student Assessment), similar consequences may flow from more informal comparisons made by policy actors. Moreover, as several of the interviewees compared students in their own country unfavourably with those in other parts of Europe, it appears that the continent constitutes not only an important frame of reference, but also one that is viewed in largely positive terms. The 'othering' associated with the articulation of distinct places as spatial imaginaries is thus notably absent from these accounts. Thus, although the extracts above do not articulate any universal characteristics of ‘Europeans' or a 'European nation' (as associated with the definition of an 'idealised spatial imaginary' outlined by Watkins), they do hint at the presence of an emerging idealised space - in which Europe is seen as providing the logical parameters for discussion, and other European nations are seen as potential sources of learning. In this way, asserting distinctiveness relative to others can be seen as a means of affirming an emerging idealised space rather than rejecting it.

This argument is supported further by considering the cases of Denmark and England. In both nations, there were many fewer comparisons with other European nations than in Germany, Ireland, Poland and Spain, and policy influencers typically did not identify similarities and/or 
differences between their national students and those from other European countries.

Moreover, as Table 2 demonstrates, there were also fewer references to Europe or Europeans in general in the policy documents from both countries and the English interviews. This relative absence of a European frame of reference articulates with the broader political positioning of both countries and, in particular, their apparent reluctance to conceive of Europe as an idealised space. Although Denmark's higher education system has been quite significantly influenced by various European reforms (Degn and Sorensen, 2015; Mosneaga and Agergaard, 2012), the widely documented 'soft Euroscepticism' in the nation, articulated by parties on both the left and right of the political spectrum (Fitzgibbon, 2013), has mitigated against the construction of Europe as an idealised space within national debate. Within England, Euroscepticism has taken a 'harder' form - culminating in the referendum vote in June 2016 to leave the EU (Gifford, 2014) - and policymakers have also been more reluctant to implement European initiatives within education (Alexiadou and Lange, 2014). These particular relationships to the EU may help explain why the interviewees and the authors of the various policy documents analysed did not draw on comparisons with other European nations to help explain the characteristics of their own domestic student body. In the English accounts and, to a lesser extent, those from Denmark, Europe was invoked neither as a distinct place nor an emerging idealised space.

[Insert Table 2 here]

Europeanisation as spatial transformation

A further way in which Europe was invoked as a spatial imaginary was with respect to putative changes brought about by processes of Europeanisation - through, for example, 
discussion of the Bologna reforms and the establishment of a European Higher Education Area. Here, we see Watkins' notion of spatial imaginary as spatial transformation played out. Policy actors differed, however, in how such transformations were evaluated, even within the same nation-state.

As Table 2 demonstrates, the Bologna Process was mentioned frequently in the interviews in Germany and Spain, but hardly at all in the other four countries. With respect to the policy documents, it was a reasonably important point of reference in Germany, Ireland, Poland and particularly Spain, but virtually absent from the Danish and English documents. In Germany, alongside the positive statements about Europe as a distinct place - fostered to some extent through the perspectives of the 'Erasmus generation' discussed above - some interviewees also emphasised the benefits brought about by the Bologna Process which, they suggested, was radically transforming higher education in Europe. The interviewee from the German rectors' conference, for example, welcomed the new focus on viewing students as partners in teaching and learning, encouraged by Bologna, believing this to be a positive shift away from the hierarchical relations that had sometimes characterised interactions between students and staff:

in our organisation and in our dealings with the ministries and with the student organisations and so on, there's a clear consensus that the students are partners in the teaching and learning endeavour. That has developed, this perception has developed very strongly under the influence of Bologna.

In addition, the interviewee from the employers' organisation believed that the structural change to German degrees - and particularly the opportunity to enter the labour market after 
completion of a bachelor's degree (rather than having to progress automatically to a master's) - was a positive development for both students and employers:

We supported [the Bologna reform] that it is possible to make a Bachelor degree and then enter the world of work .... we would ... strongly support it if more students all graduated with a Bachelor degree do this way and enter the ... the world of work.

The transformative effects of Bologna were evaluated less positively in other respects, however. Indeed, the interviewee from the German rectors' conference believed that the Bologna reforms had imposed upon European nations a narrow view of higher education, associated primarily with skills, employability and preparation for the labour market, which marginalised the many other important functions of higher education. The interviewee from the employers' organisation noted that this was a common view within the German higher education sector, attributing it to, first, the historical strength of the vocational sector in Germany and the associated belief that it was not the role of the academic sector to prepare students for the labour market and, second, the lower rates of unemployment relative to other European countries over recent years. The students' union representative was also critical of the Bologna reforms - partially because of their perceived labour market focus, but also because of the structural changes they had introduced (in which, for example, there was no automatic progression to a master's degree) and the imposition of managerial (rather than collegial) forms of university governance. Although such varying perspectives provide strong evidence that nations are not necessarily 'coherent educational entities' (Philips and Schweisfurth, 2014) with respect to key actors' understandings of students and the sector more generally, interviewees shared a belief in Bologna (as a key aspect of Europeanisation) as a transformative force. 
Similar narratives were evident in Spain, in which the Bologna reforms were seen by many policy actors as transformative but, again, were not always evaluated in the same way. For example, while interviewees from the HEI leaders' organisation thought that the Bologna reforms had prompted a closer focus on students within higher education, and the government interviewee welcomed the inclusion of more practical and skills-based elements to degree courses, the union interviewee had a markedly different perspective. He agreed that Bologna had wrought significant change in Spain, but believed this had been to the detriment of students and Spanish society more generally. In particular, he thought that the shortening of the Spanish first degree from five years to four had forced many students to study for a master's degree - as employers no longer considered the bachelor's degree (because of its shorter length) adequate for employment. He commented starkly, 'Most of the degrees students get at the end of their studies have no value'.

More nations discussed processes of Europeanisation in general rather than Bologna specifically (see Table 2), although again Denmark and England differ from the other four nations in the relative absence of such discussions from the interviews (in the case of England) and the policy documents (with respect to both countries). In Poland, for example, Europeanisation was brought up by a number of the interviewees. Here, discussion typically focussed on Poland's closer relationship with western nations through accession to the European Union, and the consequent ease of mobility between nation-states. For example, one of the Polish government interviewees noted:

When I was a student there were very few opportunities to send someone abroad. Now, with Erasmus, if you want to spend one year abroad, it is no problem, there is no obstacle.

(Government interviewee 1) 
He also outlined his belief that students had become more demanding, stating that they now expected a well-paid job on graduation (and were resistant to the idea of working their way up within an organisation), as well as state-provided scholarships, accommodation, and a pension - but also wanted lower taxes. He thought that these 'demanding attitudes' were likely to be a result of greater international mobility on the part of Polish young people, and their increasing exposure to what they viewed as higher standards of living in the West. The discussion of Europe within the Irish documents and interviews was rather different in nature, as might be expected given Ireland's longer history of EU membership. For example, the HE leaders' interviewee noted that Irish policies relating to student empowerment - making contributions to how their learning was organised - had been informed by practice in other countries, while one of the government officials noted that Ireland was now focussing on recruiting a larger number of older students to higher education because of European imperatives under the Lisbon process.

The examples provided above demonstrate that, in some nations, the impact of Bologna and other education-related processes of Europeanisation, was not always seen in the same way by all policy actors, and individual policy influencers often articulated what they saw as both positive and negative impacts of particular reforms. Nevertheless, in Germany, Spain, Poland and Ireland, the idea of 'Europeanisation', in some guise at least, provided an important point of reference for many discussions. Implicit in various interview responses in these countries was a sense that spatial transformation had occurred or was occurring, with European initiatives playing a greater role within and with respect to the nation-state. Such narratives can be considered as performative in nature - reinforcing the idea that 'Europe' (whether understood as the European Union, Bologna process, or just closer relations with other European nations) is a significant influence on what happens nationally. Moreover, although 
some interviewees mentioned various negative impacts of 'Europeanisation', the absence of any wholesale rejection of this source of influence can be read as an implicit - if not explicit - acceptance of the legitimacy of 'Europe' as a new spatial frame. However, such positions with respect to Europeanisation are also related to specific national histories and geo-political orientations. In relation to Spain, for example, Bonal and Tarabini (2013) have argued that Spanish official discourse (including pronouncements about education policy) constantly underlines the advantages of Europeanisation as a means of advancing both social and economic progress. They contend that "in order to become "real Europeans" it is crucial to follow the reforms already implemented by other European countries' (p.337). More generally, scholars have explained Spain's current positive orientation to Europe as part of a strong desire to chart a different course from the isolation it experienced historically - as a result of its detachment from international affairs during much of the $18^{\text {th }}$ and $19^{\text {th }}$ centuries and from the beginnings of the process of European integration during the Franco dictatorship (Ross et al., 2016). Moreover, Ross (2009) has argued that Spain, unlike nations such as Britain, has not had 'an unthinkingly accepted common notion of nationhood to which European integration posed a threat' (p.190).

Indeed, in England and Denmark the absence of reference to processes of Europeanisation or Europe as a 'spatial transformation' is notable - despite both countries being members of the European Union (at the time of data collection) and the European Higher Education Area, and active participants in the Erasmus programme. This is consonant with the national politics in both nations outlined above, in which Euroscepticism has been influential, albeit in a 'softer' form in Denmark than in England (Fitzgibbon, 2013; Nielsen, 2015) and, in England's case, a history of successfully resisting many European policy initiatives and having had to make little adjustment to its higher education policy to accommodate the 
Bologna reforms (Alexiadou and Lange, 2014; Capano and Piattoni, 2013). Indeed, rather paradoxically, these national variations in the extent to which Europeanisation is positioned as a transformative spatial imaginary provide support for Capano and Piattoni's (2011) contention that European policy should be conceived as a 'cultural script' taken up by countries according to their national priorities. The spatial imaginary of 'Europeanisation' is thus not necessarily pan-European in its reach.

\section{Conclusion}

This article has argued that, as Carlson et al. (2013) have maintained, Europe is considered significant for many policymakers across the continent. For many, although not all, of those we interviewed, Europe acted as a spatial imaginary - providing various socially-embedded stories that constitute particular ways of talking about specific places. However, differences were also identified in relation the kind of spatial imaginaries deployed. Europe was seen as a distinct place in only the German data, shown in the various speeches quoted above.

However, we have contended that Europe constituted an idealised space in many more countries. This was typically implicit and articulated in relation to emerging idealised spaces, seen in the comparisons interviewees drew between students in different countries. While this could be seen as a means of asserting the distinctiveness of nation-states, the importance of this European frame of reference, and the positive ways in which students from other European countries were viewed, suggests instead the beginnings of a common idealised space. Europe was also perceived as closely entangled with processes of spatial transformation - evidenced in discussions about the significant change brought about by the Bologna Process, the EHEA, Erasmus, and other forms of education-related Europeanisation. 
Differences were also evident across nations. Denmark and England differed from the other four countries in seemingly resisting European spatial imaginaries which we explained in the discussion above in relation to their different internal politics (particularly the influence of Euroscepticism) and their positioning within Europe. It appears that the Danish and English national stories cannot accommodate easily the idea of Europe as a distinct place, an idealised space or a transformative force (even when European initiatives, such as Erasmus, clearly play an important role within their higher education systems). Such variation raises questions about claims of homogenisation across Europe and, instead, lends weight to those who have highlighted significant variation by nation-state with respect to various European policies and programmes (e.g. Shaw et al., 2013; Soltys, 2015). However, in contrast to some of these studies that have emphasised significant diversity between both nations and actors within them (e.g. Neave and Veiga, 2013), this analysis has demonstrated much greater convergence across four of the six countries - with respect to Europe operating as an important spatial imaginary.

The research documented here thus contributes to the literature on education (and specifically on the Europeanisation of higher education) by showing the extent to which ideas about Europe frame the narratives of policy influencers and are invoked in national policy documents. This is important because of the performative role spatial imaginaries can play not only representing ways in which Europe is understood, but exerting influence on such understandings. Indeed, there is now a sizable literature on the impact of both spatial frames of reference (e.g. Watkins, 2015) and conceptualisations of the social world within policy (Bacchi, 2000; Ball, 1990). These are likely to impact students themselves (as well as broader public discourses) who may as a result - in some national contexts but not others - come to see themselves positioned as European citizens (see also Brooks, 2018b and 2019). The 
article also contributes to scholarship on spatial imaginaries by showing how the articulation of place distinctiveness can, paradoxically, contribute to the formation of idealised spaces, albeit in an emerging form.

\section{Acknowledgements}

I would like to thank all those who kindly gave up their time to be interviewed, the Eurostudents project advisory group for their feedback on the choice of documents, and the referees who provided very constructive feedback. I am also very grateful to the European Research Council for the award of a Consolidator Grant (reference 681018_EUROSTUDENTS), which funded this research.

\section{References}

Alexiadou, N. and Lange, S. (2014) Policy space and the governance of education: transnational influences on institutions and identities in the Netherlands and the UK, Comparative Education, 49, 3, 344-360.

Amaral, A. (2008) Transforming Higher Eduction, in: Amaral, A., Bleiklie, I. and Musselin, C. (eds) From Governance to Identity, Springer.

Amaral, A., Neave, G., Musselin, C. and Maassen, P. (eds) (2009) European Integration and the Governance of Higher Education and Research, Springer. 
Bacchi, C. (2000) Policy as discourse: What does it mean? Where does it get us? Discourse: Studies in the Cultural Politics of Education, 21, 1, 45-57.

Ball, S. (1990) Politics and Policy Making in Education: explorations in policy sociology New York, Routledge.

Berndtson, E. (2013) Contradictions of the Bologna Process: academic excellence versus political obsessions, European Political Science, 12, 440-447.

Bock, J.-J. and Mcdonald, S. (2019) Making, experiencing and managing difference in a changing Germany, in: Bock, J.-J. and Mcdonald, S. (eds) Refugees Welcome? Difference and Diversity in a Changing Germany New York, Berghahn Books pp. 1-38.

Bonal, X. and Tarabini, A. (2013) The role of PISA in shaping hegemonic educational discourses, policies and practices: the case of Spain, Research in Comparative and International Education, 8, 3, 335-341.

Brooks, R. (2018a) Understanding the higher education student in Europe: a comparative analysis, Compare: A Journal of Comparative and International Education, 48, 4, 500-517.

Brooks, R. (2018b) Higher education mobilities: a cross-national comparison, Geoforum, 93, 87-96. 
Brooks, R. (2019) The construction of higher education students within national policy: a cross-European comparison, Compare: A Journal of Comparative and International Education. (Advance online access)

Bürkner, H.-J. and Scott, J. (2019) Spatial imaginaries and selective in/visibility: mediterranean neighbourhood and the European Union's engagement with civil society after the 'Arab Spring', European Urban and Regional Studies, 26, 1, 22-36.

Cairns, D., Krzaklewska, Cuzzocrea, V. and Allaste, A.-A. (2018) Mobility, Education and Employability in the European Union Basingstoke, Palgrave.

Capano, G. and Piattoni, S. (2011) From Bologna to Lisbon: the political uses of the Lisbon 'script' in European higher education policy, Journal of European Public Policy, 18, 4, 584606.

Carlson, S., Eigmüller, M. and Lueg, K. (2018) Education, Europeanisation and Europe's social integration, Innovation, 31, 4, 395-405.

Corbett, A. (2005) Universities and the Europe of Knowledge. Ideas, Institutions and Policy Entrepreneurship in European Union Higher Education Policy, 1955-2005. Basingstoke, Palgrave.

Corbett, A. and Henkel, M. (2013) The Bologna dynamic: strengths and weaknesses of the Europeanisation of higher education, European Political Science, 12, 415-423. 
Dakowska, D. (2015) Between competition imperative and Europeanisation: the case of higher education reform in Poland, Higher Education, 69, 129-141.

Dakowska D. and Harmsen, R. (2015) Laboratories of reform? The Europeanization and internationalization of higher education in Central and Eastern Europe, European Journal of Higher Education, 5, 1, 4-17.

Degn, L. and Sørensen, M. (2015) From collegial governance to conduct of conduct: Danish universities set free from the service of the state, Higher Education, 69, 931-946.

Desrosières, A. (1998) The Politics of Large Numbers: A History of Staistical Reasoning Cambridge, MA, Harvard University Press.

Dobbins, M. (2011) Higher Education Policies in Central and Eastern Europe. Convergence Towards a Common Model? Basingstoke, Palgrave.

Dobbins, M. and Knill, C. (2017) Higher education governance in France, Germany, and Italy: Change and variation in the impact of transnational soft governance, Policy and Society, 36, 1, 67-88.

Eurydice (2017) National Student Fee and Support Systems in European Higher Education 2017/18 Available online at:

https://webgate.ec.europa.eu/fpfis/mwikis/eurydice/images/e/e7/214_EN_Fees_and_support 2017 18.pdf (Accessed 23/4/18). 
Fitzgibbon, J. (2013) Citizens against Europe? Civil society and Eurosceptic protest in Ireland, the United Kingdom and Denmark, Journal of Common Market Studies, 51, 1, 105121.

Gifford, C. (2014) The Making of Eurosceptic Britain (second edition) London, Routledge.

Gornitzka, A. (2007) The Lisbon Process: a supranational policy perspective, in: Maassen, P. and Olsen, J. (eds) University Dynamics and European Integration, Springer.

Grek, S. (2015) Travelling the 'Caledonian Way': education policy learning and the making of Europe, Evidence and Policy, 11, 2, 209-224.

Grek, S., Lawn, M., Lingard, B., Ozga, J., Rinne, R., Seherhom, C. and Simola, H. (2009) national policy brokering and the construction of the European Education Space in England, Sweden, Finaland and Scotland, Comparative Education, 45, 5-21.

Itaoui, R. (2016) The geography of Islamophobia in Sydney: mapping the spatial imaginaries of young Muslims, Australian Geographer, 47, 3, 261-279.

Keeling, R. (2006) The Bologna Process and the Lisbon Research Agenda: the European Commission's expanding role in higher education discourse, European Journal of Education, $41,2,203-223$. 
Kerber, W. and Eckardt, M. (2007) Policy learning in Europe: the open method of coordination and laboratory federalism, Journal of European Public Policy, 14, 2, 227-247.

Kundnani, H. (2014) The Paradox of German Power London, C. Hurst and Co.

Lawn, M. (2009) Soft governance and the learning spaces of Europe, Comparative European Politics, 4, 2-3, 272-288.

Lueg, K. (2018) Organizational changes towards a European academic field. A case study of frictions in the narratives of Europeanisation at a German university from an institutional perspective, Innovation, 31, 4, 484-503.

Maassen, P. and Musselin, C. (2009) European Integration and the Europeanisation of Higher Education, in: Amaral, A., Neave, G., Musselin, C., Maassen, P. (Eds.) European Integration and the Europeanisation of Higher Education Springer.

Mcdonald, S. (2019) Refugee futures and the politics of difference, in: Bock, J.-J. and Mcdonald, S. (eds) Refugees Welcome? Difference and Diversity in a Changing Germany New York, Berghahn Books pp. 311-331.

Moutsios, S. (2013) The de-Europeanization of the university under the Bologna process. Thesis Eleven, 119, 1, 22-46. 
Münch, R. (2013) The Bologna Process in the German system of higher education: from occupational monopolies to the global struggle for educational prestige, European Political Science, 12, 424-431.

Musselin, C. (2009) The side effects of the Bologna process on national institutional settings, in Amaral, A., Neave, G., Musselin, C. and Maassen, P. (eds) European Integration and the Governance of Higher Education and Research, Dordrecht, Springer pp.281-299.

Neave, G. and Veiga, A. (2013) The Bologna Process: inception, 'take up' and familiarity, Higher Education, 66, 59-77.

Nielsen, J. H. (2015) The pragmatic Euroscepticism of Scandinavia, in: Leruth, B., Startin, N. and Usherwood, S. (eds) Routledge Handbook of Euroscepticism London, Routledge.

Philips, D. and Schweisfurth, M. (2014) Comparative and International Education London, Continuum.

Ravinet, P. (2008) From Voluntary Participation to Monitored Coordination: why European countries feel increasingly bound by their commitment to the Bologna Process, European Journal of Education, 49, 3, 353-369.

Ravinet (2018) On Principles, Europe and Higher Education: Refelctions on European Higher Education as an Intersecting Normative Space, in: Sin, C., Tavares, O., Cardoso, S. and J. Rosa, M. (eds) European Higher Education and the Internal Market. Tensions between European Policy and National Sovereignty Basingstoke, Palgrave. 
Rizvi, F. and Lingard, B. (2010) Globalizing Education Policy London, Routledge.

Robertson, S. (2009) Europe, Competitveness and Higher Education: an evolving project, in Dale, R. and Robertson, S. (eds) Globalisation and Europeanisation in Education Oxford, Symposium Books.

Ross, C. (2009) Spain Since 1812 London, Hodder Stoughton.

Ross, C., Richardson, B. and Sangrador-Vegas, B. (2016) Contemporary Spain London, Routledge.

Said, E. (2003) Orientalism London, Penguin.

Shaw, M., Chapman, M. and Rumyantseva, N. (2013) Organizational culture in the adoption of the Bologna Process: a study of academic staff at a Ukrainian university, Studies in Higher Education, 38, 7, 989-1003.

Sin, C. and Tavares, O. (2018) The Bologna Process and the Unachieved Potential for the Creation of a Common Higher Education Market, in: Sin, C., Tavares, O., Cardoso, S. and J. Rosa, M. (eds) European Higher Education and the Internal Market. Tensions between European Policy and National Sovereignty Basingstoke, Palgrave. 
Soltys, D. (2015) Similarities, divergence and incapacity in the Bologna Process reform implementation by the former socialist countries: the self-defeat of state regulations, Comparative Education, 51, 2, 179-195.

Szolár, E. (2011) The Bologna Process: the reform of the European higher education system, Romanian Journal of European Affairs, 11, 1, 81-99.

Sykes, O. (2018) Post-geography worlds, new dominions, left behind regions and 'other' places: unpacking some spatial imaginaries of the UK's 'Brexit' debate, Space and Polity, 22, $2,137-161$

Voegtle, E., Knill, C. and Dobbins, M. (2011) To what extent does transnational communication drive cross-national policy convergence? The impact of the Bologna Process on domestic higher education policies, Higher Education, 61, 77-94.

Watkins, J. (2015) Spatial imaginaries research in geography: synergies, tensions and new directions, Geography Compass, 9, 9, 508-522.

Wetzstein, S. (2013) Globalizing economic governance, political projects and spatial imaginaries: insights from four Australasian cities, Geographical Research, 51, 1, 71-84. 
Table 1. Characteristics of the countries involved in the research

\begin{tabular}{|c|c|c|c|c|}
\hline Country & $\begin{array}{l}\text { Welfare } \\
\text { regime }\end{array}$ & $\begin{array}{l}\text { Access- } \\
\text { ion to } \\
\text { the EU }\end{array}$ & $\begin{array}{l}\text { Tuition fees for full- } \\
\text { time undergraduates } \\
(2017 / 18)\end{array}$ & $\begin{array}{l}\text { Student support for full-time } \\
\text { undergraduates }(2017 / 18) \text { - with } \\
\text { amounts per annum }^{i}\end{array}$ \\
\hline $\begin{array}{l}\text { Denmar } \\
\mathrm{k}\end{array}$ & $\begin{array}{l}\text { Social } \\
\text { democratic }\end{array}$ & 1973 & No tuition fees & $\begin{array}{l}\text { c. } 85 \text { per cent receive needs-based } \\
\text { grants (of up to } € 9703 \text { ); loans } \\
\text { available to those entitled to state } \\
\text { grant }\end{array}$ \\
\hline England & Liberal & $\begin{array}{l}1973 \\
\text { (to } \\
\text { leave } \\
\text { in } \\
\text { 2019) }\end{array}$ & $\begin{array}{l}\text { High fees, typically } \\
£ 9250 \text { per year }\end{array}$ & No grants; loans available to all \\
\hline $\begin{array}{l}\text { German } \\
\text { y }\end{array}$ & Corporatist & 1952 & $\begin{array}{l}\text { No tuition fees; } \\
\text { administrative fee of } \\
\text { up to } € 300 \text { per } \\
\text { semester }\end{array}$ & $\begin{array}{l}\text { c. } 25 \text { per cent of students receive } \\
\text { need-based grants (up to } € 8820- \\
\text { includes integrated loan) }\end{array}$ \\
\hline Ireland & $\begin{array}{l}\text { Catholic } \\
\text { corporatist }\end{array}$ & 1973 & $\begin{array}{l}\text { No tuition fees; } \\
\text { 'student contribution' } \\
\text { of } € 3000 \text { per year }\end{array}$ & $\begin{array}{l}\text { c. } 44 \text { per cent of students receive } \\
\text { need-based grants (up to €5915); } \\
\text { no loans available }\end{array}$ \\
\hline Poland & $\begin{array}{l}\text { Post- } \\
\text { Communist }\end{array}$ & 2004 & $\begin{array}{l}\text { No tuition fees; one- } \\
\text { off administrative fee } \\
\text { of c. } € 47 \text { per year }\end{array}$ & $\begin{array}{l}\text { c. } 16 \text { per cent of students receive } \\
\text { need-based grants }(€ 1244) \text { and } 8 \\
\text { per cent merit-based grants } \\
\text { (average } € 1113 \text { ); loans available to } \\
\text { those on lower incomes }\end{array}$ \\
\hline Spain & $\begin{array}{l}\text { Mediterrane } \\
\text { an/ } \\
\text { sub- } \\
\text { protective }\end{array}$ & 1986 & $\begin{array}{l}\text { c. } 71 \text { per cent of } \\
\text { students pay fees; } \\
\text { average amount of } \\
€ 1213 \text { per year }\end{array}$ & $\begin{array}{l}\text { c. } 30 \text { per cent of students receive } \\
\text { need-based grants (up to } € 6682 \text { ); } \\
\text { no loans available }\end{array}$ \\
\hline
\end{tabular}

Table 2. Number of times relevant terms mentioned in documents and interviews

\begin{tabular}{lcccccc}
\hline & \multicolumn{2}{c}{ Europe/European } & \multicolumn{2}{c}{ Bologna Process } & \multicolumn{2}{c}{ Erasmus } \\
\hline & Interviews & Documents & Interviews & Documents & Interviews & Documents \\
\hline Denmark & 25 & 14 & 1 & 1 & 0 & 2 \\
England & 8 & 33 & 0 & 2 & 0 & 0 \\
Germany & 36 & 347 & 32 & 17 & 0 & 33 \\
Ireland & 48 & 166 & 0 & 15 & 1 & 12 \\
Poland & 32 & 134 & 1 & 14 & 3 & 7 \\
Spain & 17 & 617 & 16 & 94 & 2 & 37 \\
\hline
\end{tabular}

\footnotetext{
${ }^{\text {i }}$ Source: Eurydice (2017)
} 